\title{
Seed degeneration in potato: the need for an integrated seed health strategy to mitigate the problem in developing countries
}

\author{
S. Thomas-Sharma* ${ }^{a *}$ A. Abdurahman ${ }^{\mathrm{b}}$, S. Ali ${ }^{\mathrm{c}}$, J. L. Andrade-Piedra ${ }^{\mathrm{d}}$, S. Bao ${ }^{\mathrm{e}}$,

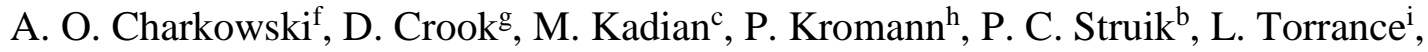 \\ K. A. Garrett ${ }^{\text {aj }}$ and G. A. Forbes ${ }^{\mathrm{g}}$ \\ ${ }^{a}$ Department of Plant Pathology, Kansas State University, Manhattan, KS, USA ${ }^{b}$ Centre for Crop Systems Analysis, \\ Plant Sciences, Wageningen University, Wageningen, The Netherlands; 'International Potato Center, New Delhi, \\ India; ${ }^{d}$ International Potato Center, Lima, Peru; ${ }^{e}$ Potato E\&T Research Center, Inner Mongolia University, \\ Hohhot, China; ${ }^{f}$ Department of Plant Pathology, University of Wisconsin-Madison, Madison, WI, USA; \\ ${ }^{g}$ International Potato Center, Kunming, China; ${ }^{h}$ International Potato Center, Quito, Ecuador; ${ }^{i}$ Cell and Molecular \\ Sciences, The James Hutton Institute, Dundee, UK; and ${ }^{j}$ Institute for Sustainable Food Systems and Plant Pathology \\ Department, University of Florida, Gainesville, FL, USA
}

Seed potato degeneration, the reduction in yield or quality caused by an accumulation of pathogens and pests in planting material due to successive cycles of vegetative propagation, has been a long-standing production challenge for potato growers around the world. In developed countries this problem has been overcome by general access to and frequent use of seed, produced by specialized growers, that has been certified to have pathogen and pest incidence below established thresholds, often referred to as certified seed. The success of certified seed in developed countries has concentrated the research and development agenda on the establishment of similar systems in developing countries. Despite these efforts, certified seed has had little penetration into the informal seed systems currently in place in most developing countries. Small-scale farmers in these countries continue to plant seed tubers acquired through the informal seed system, i.e. produced on-farm or acquired from neighbours or local markets. Informal seed tubers frequently have poor health status, leading to significant reductions in yield and/or market value. This review emphasizes the need to refocus management efforts in developing countries on improving the health status of seed tubers in the informal system by integrating disease resistance and on-farm management tools with strategic seed replacement. This 'integrated seed health strategy' can also prolong the good health status of plants derived from certified seed, which would otherwise be diminished due to potential rapid infection from neighbouring fields. Knowledge gaps, development challenges and impacts of this integrated seed health strategy are discussed.

Keywords: certified seed, potato virus, quality-declared seed, seed degeneration, seed potato, Solanum tuberosum

\section{Introduction}

Pathogen and pest build-up in potato seed tubers (seed degeneration) is arguably one of the primary causes of low potato productivity in developing countries (Fuglie, 2007; Gildemacher et al., 2009; Cromme et al., 2010). The commonly proposed solution to this problem has been to increase availability and farmers' access to seed material produced off-farm by specialized seed producers, often government-regulated to certify a minimum health status (Cromme et al., 2010; Frost et al., 2013; Mateus-Rodriguez et al., 2013; Kaguongo et al., 2014). However, certified seed has had little penetration into local seed systems in developing countries (Tripp, 1997; Thiele, 1999). Because most farmers continue to use farm-/neighbour-saved seed or seed from informal seed producers, improving the health

*E-mail: thomasuga@gmail.com of on-farm seed material is necessary. This review discusses how advocating the use of certified seed as a silver bullet to manage degeneration may be overly simplistic, and how integrating host resistance and onfarm management tools with strategic seed replacement with certified seed (or other similar sources of high quality seed such as 'quality-declared seed') will make degeneration management in developing countries more resilient. Although the principles of integrated disease management are established for many diseases, the authors are not aware of papers discussing its importance for the management of vegetative seed material. A move towards an 'integrated seed health strategy' would require amendments to existing research and development agendas, but such a paradigm shift should improve the productivity of vegetatively propagated crops in general, including food security staples such as potato, and therefore the livelihood of smallholder farmers. 
Potato (Solanum tuberosum) is the third most important food crop globally (FAO, 2013), and over half of all production occurs in developing countries (Devaux et al., 2014). The high yield potential of potato per hectare of arable land, good nutritive value, and cooking versatility have led to a tripling of potato consumption in the developing world, from $6 \mathrm{~kg} / \mathrm{capita}$ year $^{-1}$ in 1969 to $18 \mathrm{~kg} / \mathrm{capita}$ year $^{-1}$ in 2009 (Lutaladio \& Castaldi, 2009). Potato's short cropping cycle allows it to serve as a hunger-breaking crop, and makes it suitable for intercropping and double cropping, especially in cereal-based production systems in Africa and Asia (Cromme et al., 2010) and in cropping systems where the main crop has a long establishment period, such as sugarcane plantations in Mauritius (Govinden, 1990). However, potato yields are relatively low in developing countries (Table 1; FAO, 2013) and seed degeneration is considered a major cause of this low productivity (Fuglie, 2007; Gildemacher et al., 2009; Cromme et al., 2010).

Potatoes are primarily propagated vegetatively via tubers, although sexual propagation via botanical seed, called true potato seed (TPS), is also possible. In general, pathogens pass more readily to asexual propagules than to sexual propagules, and so, in potato, seed tubers are much more likely to harbour a wide range of pathogens compared with TPS. Potatoes grow below ground and are exposed to many soilborne

Table 1 Per capita consumption and yield of potato in selected countries (FAO, 2011, 2013)

\begin{tabular}{lcl}
\hline Country & $\begin{array}{l}\text { Per capita } \\
\text { consumption, }\end{array}$ & $\begin{array}{l}\text { Yield, 2013 } \\
\text { (tonnes ha-1) }\end{array}$ \\
Developing countries & 2011 (kg year $\left.{ }^{-1}\right)$ & \\
Angola & 27.7 & \\
Bangladesh & 45.2 & 6.3 \\
Bolivia & 66.0 & 19.4 \\
China & 41.2 & 5.8 \\
Colombia & 27.4 & 15.4 \\
Ecuador & 18.9 & 18.6 \\
Fiji & 26.9 & 7.3 \\
India & 25.0 & 6.1 \\
Kazakhstan & 108.2 & 22.8 \\
Kyrgyzstan & 100.8 & 18.2 \\
Libya & 34.7 & 16.6 \\
Malawi & 106.8 & 19.7 \\
Nepal & 75.1 & 17.5 \\
Peru & 82.4 & 13.6 \\
Rwanda & 99.9 & 14.4 \\
Tunisia & 30.3 & 13.6 \\
Industrialized countries & 14.6 \\
Belgium & 105.9 & \\
Denmark & 59.7 & 46.2 \\
France & 54.5 & 40.0 \\
United Kingdom & 100.8 & 43.4 \\
USA & 55.6 & 40.1 \\
\hline & & 46.6 \\
\hline
\end{tabular}

pathogens and pests, presenting additional challenges to maintain the phytosanitary quality of seed tubers. Potato tubers used as planting material are generally referred to as 'seed tubers' or simply 'seed'. Here, the use of the term 'seed' refers to seed tubers, unless otherwise specified, and 'seedborne' refers to those pathogens and pests present in vegetative tubers used as planting material.

To facilitate this review, general definitions for informal and formal seed systems from Almekinders (2000) are employed. The informal seed sector is usually defined as all activities related to seed production, management and use, involving mostly small-scale farmers. In contrast, the formal sector includes activities related to seed production, management and use overseen by the public and commercial sector. Informal seed may be produced on-farm or acquired locally (e.g. markets, neighbours); formal seed is purchased from specialized growers and seed quality is generally formally regulated by public institutions through a seed certification programme. As Almekinders (2000) notes, a clear distinction between the two systems does not always exist and in many developing countries semiformal systems with intermediate forms (e.g. systems with quality-declared seed) exist. However, these definitions are useful for advancing a discussion on potato seed degeneration.

This review discusses the complex nature of potato seed degeneration, addressing epidemiological, socioeconomic, management and governance perspectives. More specifically, this paper aims to (i) synthesize the literature on the nature, causes and importance of potato seed degeneration; (ii) describe perceptions of why and how the 'certified seed replacement paradigm' has shaped the research and development agenda in developing countries; (iii) present an evidence-based integrated approach to prevent or slow down degeneration of potato seed material that is more appropriate for developing countries; and (iv) identify knowledge gaps and research challenges for formulating a potato seed health strategy.

\section{Nature, causes and importance of potato seed degeneration}

Definitions of seed degeneration

The focus on potato seed degeneration in the scientific literature was most evident several years after seed certification programmes began (in the early 1900s) in Europe and the USA (Shepard \& Claftin, 1975; Frost et al., 2013).The fact that degeneration was primarily caused by viruses was discovered then and studies that unraveled the epidemiological principles of degeneration were initiated (Whipple, 1919; Folsom et 
al., 1926; Brown, 1929; Whitehead, 1930). Accordingly, Whitehead (1930) defined degeneration as an increase in the incidence of plants with virus symptoms and a concomitant reduction in yield. It is now known that increased incidence and/or severity of non-viral seedborne pathogens can also contribute to yield reductions. Moreover, damage caused by pathogens and pests reduces not only yield, but also market value. Struik \& Wiersema (1999) defined degeneration as 'a decrease in the quality of the seed [tubers] from continued propagation, mostly caused by a decrease in health status'. Building on these definitions and specifying the causes of degeneration, seed degeneration can be defined as 'an increase in pest and/or pathogen incidence or severity, associated with reduction in yield or quality of seed tubers over successive cycles of vegetative propagation'.

Previous work on the quality of vegetative seed has been less structured than that of sexual seed, for which research methods, concepts and definitions have been defined by the International Seed Testing Association (ISTA, 2014). However, some ISTA definitions are also broadly applicable to vegetative seed, such as the term 'seed quality' (Table 2; Fig. 1).

Some authors include disorders resulting from advanced physiological age of tubers as part of seed degeneration (Kawakami, 1962; Iritani, 1968). However, the authors of this review consider physiological age, physiological disorders and physical abnormalities, which are generally reversible within one generation of adequate management, to be components of potato seed quality. This is differentiated from pestor pathogen-induced seed degeneration, which tends to increase over time in the absence of management. Unlike physiological disorders, pathogens can also spread to neighbouring plants. The authors propose the term 'seed health' to refer specifically to the severity and/or incidence of pests and pathogens in tubers; and seed health would then be another characteristic of seed quality (Fig. 1). This article thus describes degeneration

Table 2 Glossary of key terms related to potato seed degeneration and its management

Certified seed
Efficiency of autoinfection seed system
Formal system
Informal seed sysiological age
Phant selection
Potato value chains
Quality-declared seed
Roguing

Seed degeneration

Seed health

Seed quality

Seed systems

Technography

Tuber-uniting
Seed produced within the formal seed system by specialized growers that has been certified to have pathogen and/or pest incidence or severity below established thresholds. Commonly used synonyms include 'clean seed' and 'disease-free seed'

Percentage of infected progeny tubers obtained from an infected mother plant (Bertschinger, 1992)

The activities of the public and commercial sector, including seed growers, related to seed production, management and use; seed quality is generally formally regulated by public institutions (Almekinders, 2000)

The activities of mostly small-scale farmers, relating to seed production, management and use (Almekinders, 2000)

Physiological status of the seed tuber as affected by its chronological age and other modifying factors such as growth history, storage conditions and treatments that influence tuber dormancy, sprouting and growth vigour (Struik \& Wiersema, 1999)

Selection of symptomless plants as seed source under high disease intensity (positive selection) or rejection of plants with symptoms as seed source under low disease intensity (negative selection)

All activities and networks of functional relationships necessary for achieving production and use of potato (Cromme et al., 2010)

Improved seed where some flexibility is allowed in implementing quality standards; used as an alternative in regions where activities to maintain high standards are difficult (FAO, 2006)

Removal of plants with symptoms within the growing season

An increase in pest and/or pathogen incidence or severity, associated with reduction in yield or quality of seed over successive cycles of vegetative propagation. Incidence of degeneration refers to the frequency of tubers infected with degenerative pathogens or pests in a seed lot. Severity of degeneration refers to pathogen and/or pest load (example virus titre) per individual diseased tuber

An attribute of seed quality that refers specifically to the severity and/or incidence of pathogens and pests

All attributes of the seed tuber that affect its value, including genetic purity, physical condition (size, shape, wounds), health condition (pathogen and/or pests) and physiological age

All institutional and non-institutional components involved in the production, management, replacement and distribution of seed tubers (Thiele, 1999)

A methodological approach in social science that uses ethnographic descriptions of technology to examine human $\mathrm{x}$ machine/tool interaction (Jansen \& Vellema, 2011)

Practice of dividing seed tubers into four pieces and planting them consecutively; it increases the efficacy of roguing because groups of infected plants are more easily identified than individual plants and allows the removal of all of the seed pieces that originated from an infected tuber 


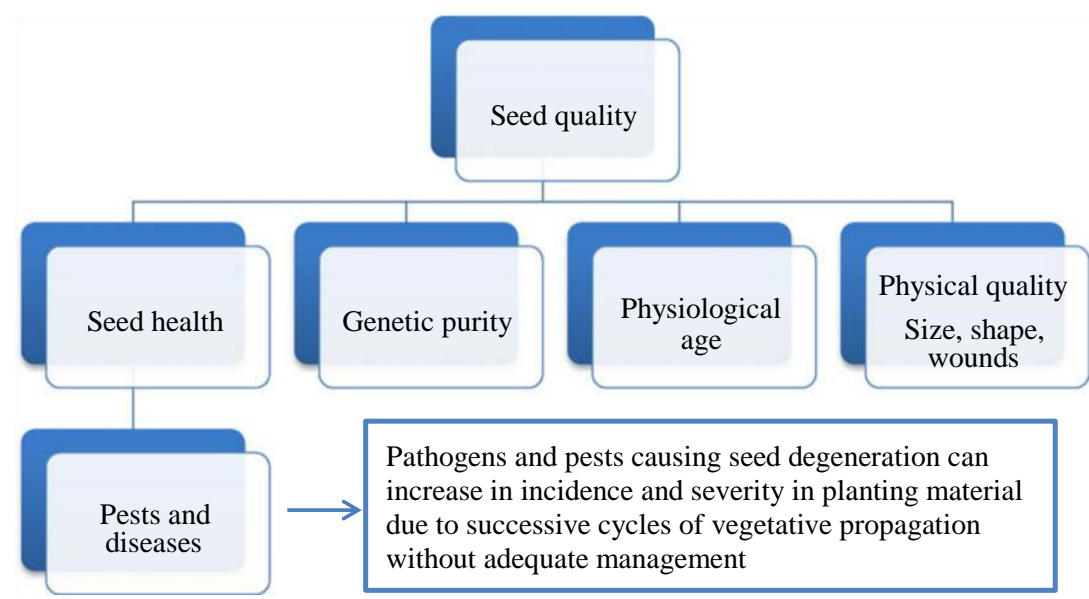

Figure 1 Proposed seed quality terminology for potato vegetative propagation. Seed quality refers to all attributes of seed tubers including genetic purity, physical condition (size, shape, wounds), health condition (pathogens and/or pests) and physiological age (including factors beyond tuber's chronological age, such as growth history, storage conditions and treatments that influence tuber dormancy, sprouting and growth vigour). Seed health refers specifically to the severity and/or incidence of pests/pathogens in seed and includes the effects of seed degeneration.

of potato seed as a manifestation of decreasing seed health, i.e. an increase in the incidence of pathogens/pests in seed.

It should also be noted that there are sometimes limits to the degree of degeneration in following generations of seed. For example, when degenerated seed is planted, host resistance to disease may protect the host population from further seed degeneration under normal production conditions. There may also be factors that lead to regeneration of seed from these plantings, such as weather unfavourable to pathogen growth.

\section{Causes of seed degeneration in potato}

Seed degeneration in potato has a complex aetiology. In addition to the many soilborne pathogens persisting in close proximity with maturing tubers, many air- or vector-borne pathogens also readily become seedborne, along with some insects and nematodes (Struik \& Wiersema, 1999). Up to 40 different pathogens cause soilborne diseases of potato (Fiers et al., 2012); however, not all are significant, nor do all survive well enough in tubers to be considered important as seedborne pathogens (Fig. 2). Furthermore, although all degeneration causing pathogens are seedborne by definition, not all seedborne pathogens contribute significantly to degeneration because they do not readily increase in incidence or severity in the seed over subsequent generations [e.g. the potato black dot pathogen Colletotrichum coccodes (Dung et al., 2012)]. Thus, although many potato pathogens may be considered seedborne, potato viruses, which generally spread systemically from parent to progeny tubers, have long been recognized as the primary cause of degeneration (Salazar, 1996; Solomon-Blackburn \& Barker, 2001). Of the c. 30 viruses infecting potatoes, Potato virus Y (PVY), Potato leafroll virus (PLRV) and Potato virus $X$ (PVX) are the most important in production systems worldwide (Scholthof et al., 2011), with PVX considered more important in combination with PVY than by itself (Salazar, 1996; Draper et al., 2002).

The relative importance of degenerative pathogens and pests varies between geographic regions, and soilborne pathogens and pests that readily become seedborne can contribute significantly towards regeneration (Fig. 2). For example, in a study in the high-altitude production areas of the Ecuadorian Andes, significant yield reduction was attributed to Rhizoctonia solani, found at an incidence of up to $78 \%$ in farmers' seed, while the generally important viruses PLRV and PVY were at an incidence of $<3 \%$ (Fankhauser, 2000). At lower altitudes in many tropical and subtropical countries, Ralstonia solanacearum, the cause of bacterial wilt, is an important component of degeneration with an incidence of up to $36 \%$ in tubers from some farms in Kenya (Mwangi et al., 2008). Dickeya spp., causing blackleg and soft rot, can spread readily as latent systemic infections in seed, and these species are emerging as major pathogens in many parts of Europe and in Israel (Toth et al., 2011). Pectobacterium spp. causing blackleg and soft rot, Clavibacter michiganensis subsp. sepedonicus causing soft rot and ring rot, and powdery scab caused by Spongospora subterranea are other pathogens that may contribute significantly to seed degeneration (Struik \& Wiersema, 1999). Nematodes such as Globodera spp. and Meloidogyne spp., whose eggs, cysts and larvae become seedborne, are important pests of seed, causing seed degeneration (Struik \& Wiersema, 1999). Seedborne insect pests, such as potato tuber moth, can also be considered important causes of degeneration in tropical countries, as they may readily become seedborne and have multiple generations in the field and in storage (Sileshi \& Teriessa, 2001; Golizadeh et al., 2014). Similarly, newly discovered viruses (Li et al., 2013), as well as emerging epidemics of Potato yellow vein virus in many South American countries (Salazar et al., 2000), potato purple top phytoplasma in the Pacific 
Figure 2 Classification of seedborne potato pathogens based on the necessity of tubers for pathogen survival between host generations. Seedborne pathogens fall in a continuum from being obligate seedborne pathogens (cause systemic infections, with tubers playing a predominant role in survival), facultative seedborne pathogens (tuber infections are common but so is survival in the abiotic environment), and opportunistic seedborne pathogens (found occasionally on tubers largely as a consequence of their soilborne nature).

Northwest of the United States (Crosslin et al., 2011) and zebra chip disease ('Candidatus Liberibacter solanacearum') in many countries (Henne et al., 2010) may develop into significant seed degeneration threats.

Factors affecting the rate of seed degeneration

The rate and expression of seed degeneration are directly and indirectly influenced by numerous environmental parameters and geographical characteristics that act not only on the host and pathogen and their interaction, but also modify vector dynamics. Whitehead (1930) observed that two experimental stations, c. $50 \mathrm{~km}$ apart in North Wales, had different patterns of potato degeneration. In the Andes, degeneration is much slower at altitudes of $>2800 \mathrm{~m}$ above sea level ( $\mathrm{m}$ a.s.1.) and even further reduced at altitudes above $3500 \mathrm{~m}$ a.s.1. (Thiele, 1999). Studies in the Andes have shown that potato viruses are sometimes found at very low incidences in potato land races or varieties that have been exposed to natural conditions for untold generations (Bertschinger et al., 1990; Fankhauser, 2000). Low levels of seed degeneration at high elevations could be because of reduced multiplication of vector and/or pathogen, which could limit disease spread. Altitude (and correlated temperature) may also affect host physiology and subsequently reduce transmission of pathogens from mother tubers to daughter tubers (Bertschinger et al., 1995a).

Research in Peru also indicates potentially complex host-pathogen interactions in degenerative diseases. One study found that virus incidence could decrease in subsequent generations (i.e. not pass from an infected mother plant to all progeny tubers) and that this phenomenon was strongly favoured by higher altitudes (Bertschinger, 1992). Bertschinger (1992) used the term 'reduced efficiency of autoinfection' (see Table 2 for definition) to describe this phenomenon. This may be
Continuum of seedborne pathogens

\begin{tabular}{|c|c|}
\hline $\begin{array}{l}\text { Facultative } \\
\text { Examples }\end{array}$ & $\begin{array}{c}\longrightarrow \text { Opportunistic } \\
\text { Examples }\end{array}$ \\
\hline Ralstonia solanacearum & Phytophthora erythroseptica \\
\hline Rhizoctonia solani & Colletotrichum coccodes \\
\hline $\begin{array}{l}\text { Globodera spp. } \\
\text { Streptomyces spp. }\end{array}$ & Pectobacterium carotovorum \\
\hline Helminthosporium solani & Sclerotinia sclerotiorum \\
\hline Fusarium spp. & Verticillium dahliae \\
\hline $\begin{array}{l}\text { Clavibacter michiganensis } \\
\text { subsp. sepedonicus }\end{array}$ & Pythium spp. \\
\hline
\end{tabular}

one manifestation of host plant resistance to viruses, while other forms of resistance involving both the virus and vector also exist (Radcliffe \& Ragsdale, 2002; Palukaitis \& Carr, 2008).

Variability in the extent of adoption and efficacy of management practices generates differences in local inoculum and pest pressure, in turn influencing both farm-level and regional epidemics. The efficacy of management practices such as selection of symptomfree planting material and roguing depends heavily on detection of disease. Symptom-based detection can be rapidly and inexpensively applied over large areas, but may miss plants with masked symptoms and latent infections (Robert et al., 2000). Serological- and nucleic acid-based techniques have increased the sensitivity, specificity and speed of identifying diseased samples. However, it should be noted that high accuracy disease management might select for viruses with mild visual symptoms, making symptom recognition-based control strategies such as roguing and plant selection (see Table 2 for definitions) less effective (van den Bosch et al., 2007; Döring, 2011). Because access to modern diagnostic kits is limited in developing countries, field detection of disease continues to rely on farmers' or inspectors' experience in recognizing symptoms.

Consequences of degeneration for ware potato production in developing countries

As with many constraints to crop productivity, accurate quantitative data on the socioeconomic consequences of potato seed degeneration are unavailable for most developing countries. Numerous studies of degeneration have been conducted by comparing plantings of healthy seed with plantings of seed exposed to natural infection for a known number of generations, but it is challenging to extrapolate these results to a larger geographic scale. These trials give an indication of the potential for losses but are not necessarily good indicators of yield losses in 
farmers' fields. For example, experimental studies rarely account for yield compensation, where healthy plants use the extra space from reduced haulm growth of their diseased neighbours to increase productivity (Struik \& Wiersema, 1999). In addition, there are inherent difficulties in determining the impact of a complex problem like degeneration, and it appears that there has been little effort at assessment because the problem is of minor importance in industrialized countries, owing to the 'certified seed replacement paradigm' (discussed below). Nonetheless, a brief review is provided of some of the literature available on yield losses in specific cases of potato seed degeneration.

In experimental plots where infected seed tubers were used, estimated losses due to PVY ranged from 29 to 85\% (Hossain et al., 1994; Mannan et al., 2008; Rahman et al., 2010), and for PLRV from 29 to 78\% (Whitehead, 1924; Rahman \& Akanda, 2010). Yield loss due to bacterial wilt varies with cultivar, climate, soil type and prevailing pathogen strains, and was reported to range from 30 to $90 \%$ in Bolivia (Elphinstone, 2005) and from 30 to $75 \%$ in parts of East Africa with occasional losses of $100 \%$ (Lemaga et al., 2005). These studies were conducted over varying numbers of years, in diverse potato-growing locations of the world and have used naturally infected plant populations or intentional mixtures of healthy and diseased plants to quantify the relationship between incidence and loss. In an example of the latter type of study, Nolte et al. (2004) concluded that a $1 \%$ increase in incidence of seedborne PVY resulted in a tuber yield reduction of $0.17-0.18 \mathrm{tha}^{-1}$, their model explaining 67$82 \%$ of variation in yield. Averaging over yearly and varietal yield differences, this translated into a maximum yield reduction of $30-40 \%$ in a crop with $100 \%$ incidence of seedborne PVY.

Another approach to estimating yield loss due to degeneration comes from studies involving multiple on farm trials where interventions have been aimed at curbing degeneration. Researchers in sub-Saharan Africa have observed yield increases of $c .30 \%$ on average with one season of positive selection (Gildemacher et al., 2011; Schulte-Geldermann et al., 2012). Given that positive selection is not $100 \%$ efficient, as farmers miss latently or even mildly infected plants, some yield loss would occur despite positive selection. Thus, these studies present a highly conservative estimate of actual yield losses in farmers' fields. A recent study in Ecuador in farmers' fields indicated that up to $29 \%$ of the yield variability could be explained by seed health (Panchi et al., 2012). Many potato workers in developing countries would probably consider $30 \%$ to be an underestimate of potential yield increase due to degeneration management, and additional efforts to accurately measure losses due to degeneration in farmers' fields, and not simply losses to disease within a season, are warranted.

\section{Approaches to degeneration management}

The certified seed replacement paradigm

From the literature of the early part of the twentieth century, it is evident that degeneration of potato was a major concern among producers and researchers (Massee, 1907; Brown, 1929; Whitehead, 1930). This concern, and the empirical observations of farmers that use of healthy seed could improve yield, quickly led to the implementation of certified seed production systems aimed at making healthy seed of improved varieties readily available to farmers in Western Europe and North America (Shepard \& Claftin, 1975; Frost et al., 2013). This certified seed was produced and distributed through strictly regulated formal seed systems involving federal or state governments, land grant universities and grower associations (Shepard \& Claftin, 1975). The systems evolved over the decades to produce seed of continuously higher quality, and were estimated to increase yields by $70-100 \%$ when high-quality seed was used regularly (Shepard \& Claftin, 1975; Monares, 1988).

The formal potato seed systems developed particularly quickly in industrialized economies where potato was the main staple food and hugely important to national food security (Shepard \& Claftin, 1975). Economic forces together with institutional and social factors were favourable to systems of commodity development based on protection of property rights and profit mechanisms (Vanloqueren \& Baret, 2009). Phytosanitary certification also became a necessity to facilitate international trade of seed potato while simultaneously limiting the movement of various quarantine pests and pathogens (deGraaf, 1994). Thus, owing to effective certified seed systems in industrialized countries, regular or even yearly replacement of seed with certified seed became the norm. The certified seed replacement paradigm became institutionalized (Fig. 3) and the problem of potato seed degeneration was relegated to a minor echelon in the hierarchy of farmer and researcher concerns.

Failure of the certified seed replacement paradigm in developing countries

The situation has been very different in the developing world where socioeconomic and agroecological contexts are different from the economies, governance and temperate climate in most of the industrialized countries. Given the success of formal, certified seed systems in the industrialized countries, the general approach to degeneration management in developing 
countries has been to establish similar formal seed systems (Monares, 1988; Thiele, 1999; Kadian et al., 2009; Labarta, 2013; Pathania et al., 2013; Kaguongo et al., 2014). These efforts have to a large extent failed as evidenced by the limited use of formal seed in the majority of developing countries (Table 3). In South and West Asia, technology for quality seed production is available, but many countries lack the infrastructure, resources, trained personnel and institutions (whether governmental or private sector) to guarantee proper implementation (Kadian et al., 2007). Kenya has an institutional framework for a formal seed system but lacks enforcement and economic backing to ensure quality (Gildemacher et al., 2009). Moreover, in Kenya and many other African countries, there are high levels of soilborne nematode, fungal and bacterial diseases, virus vectors, and solanaceous weed hosts that harbour viruses. These factors all contribute to quick contamination of healthy planting material (Were et al., 2013). An exception to the limited use of certified seed in Africa can be found in South Africa, where largescale commercial growers use certified seed produced in a system similar to the ones in place in Europe and North America (Potato Certification Service, 2015).

Undoubtedly, numerous factors contribute to the lack of success of efforts to implement formal seed systems in developing countries, including economic factors, beyond the scope of this synthesis. Thiele (1999) analysed formal seed systems in developing countries in detail, finding many potential reasons for the low demand and supply of certified seed, which include the bulky and perishable nature of seed, production risks due to adverse climate and limited access to resources, the high costs of formally certified seed, limited infrastructure and resources for formal seed programmes to ensure quality, uncertain connections to markets due to fluctuating prices, and other factors that result in poorly connected value chains. In developing countries, farmers obtain most seed from their own ware production fields, or acquire seed locally from family, neighbours, NGOs or rural markets. Specialized informal seed growers frequently provide seed only to local areas. For example, about $29 \%$ of potato fields in the North Shewa region of Ethiopia used seed from local specialized producers, while use of this kind of seed was estimated to be $<1 \%$ in Kenya and $<4 \%$ in Uganda (Gildemacher et al., 2009). Tufa (2013) noted that in Ethiopia the price difference between seed and ware potatoes was so small (close to zero) that specialized seed growers are rarely rewarded for any additional efforts taken to produce high quality seed.

The low demand for expensive certified seed also highlights the sometimes unacceptable, economic cost related to elaborate certification programmes. Although the economics behind any given seed system are multifaceted and difficult to determine in detail, it is apparent that there is a cost related to each disease tolerance threshold applied in a system, and the more stringent the threshold, the higher the cost is likely to be. For example, in the Wisconsin seed potato certification programme in the USA, the cost of seed of virussusceptible lines is higher because it takes greater effort to keep the tubers below the tolerance threshold for diseases (A. O. Charkowski, personal observation). Consequently, in risk prone and suboptimal production areas, high cost degeneration control practices (i.e. the certified seed replacement paradigm) make less economic sense. In addition, differences in priorities, lack of infrastructure, rampant corruption, absence of enforcement, and limited trust can add to the inherent difficulties in ensuring the success of formal seed systems.

\section{Toward an integrated seed health strategy}

Before certified seed systems were implemented in the industrialized countries, farmers and researchers

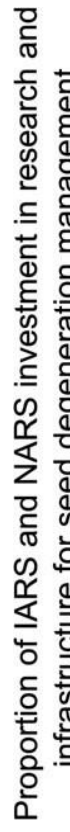

(a) Certified seed replacement paradigm

On-farm management

Host resistance

Formal seed systems (1)

(b) Integrated seed health strategy

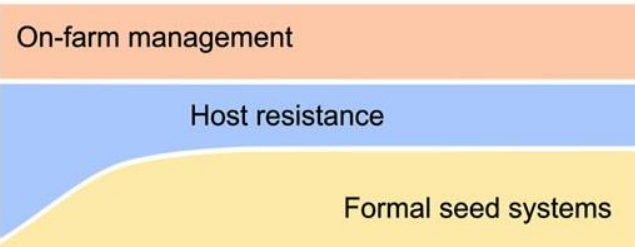

Stages in development of value chains

Figure 3 Proportion of investment by international agricultural research systems (IARS) and national agricultural research systems (NARS) in research and infrastructure for seed degeneration management in relation to the stages in development of value chains. As links to potato value chains are strengthened, (a) the certified seed replacement paradigm, which shapes current research and development, focuses on the establishment and improvement of formal seed systems with little investment in host resistance and on-farm management strategies, and (b) the integrated seed health strategy, proposed here as an alternative, focuses on integrating host resistance and onfarm management with strategic use of certified seed from formal seed systems. 
Table 3 Percentage contribution of formal potato seed system $^{\mathrm{a}}$ and informal potato seed systems ${ }^{\mathrm{b}}$ in some developing countries

\begin{tabular}{|c|c|c|c|}
\hline Country & $\begin{array}{l}\text { Formal } \\
\text { seed } \\
\text { system }\end{array}$ & $\begin{array}{l}\text { Informal } \\
\text { seed } \\
\text { system }\end{array}$ & Reference \\
\hline Afghanistan & 0 & 100 & Kadian et al. (2007) \\
\hline Bangladesh & 5 & 95 & Ilangantileke et al. (2001) \\
\hline Bhutan & 2 & 98 & Kadian et al. (2007) \\
\hline Bolivia & 2 & 98 & Hidalgo et al. (2009) \\
\hline China & 20 & 80 & Muthoni et al. (2013) \\
\hline Columbia & $2-10$ & $90-98$ & $\begin{array}{l}\text { FEDEPAPA (2010), } \\
\text { Guzman-Barney et al. } \\
(2012)\end{array}$ \\
\hline Ecuador & $1-3$ & $97-99$ & $\begin{array}{l}\text { Thiele (1999), ESPAC } \\
(2012)\end{array}$ \\
\hline Ethiopia & $11^{\mathrm{c}}$ & $89^{c}$ & Gildemacher et al. (2009) \\
\hline India & 20 & 80 & Kadian et al. (2007) \\
\hline Indonesia & 6 & 94 & Muthoni et al. (2013) \\
\hline Kenya & $0.5^{\mathrm{c}}$ & $99.5^{\mathrm{c}}$ & Gildemacher et al. (2009) \\
\hline Pakistan & 5 & 95 & Muthoni et al. (2013) \\
\hline Peru & 0.5 & 99 & Hidalgo et al. (2009) \\
\hline Uganda & $4^{\mathrm{c}}$ & $96^{\mathrm{c}}$ & Gildemacher et al. (2009) \\
\hline
\end{tabular}

${ }^{a}$ Formal potato seed system includes regulated certified seed and tubers from specialized seed producers.

bInformal potato seed systems include seed produced on-farm or acquired from neighbours or local markets.

${ }^{c}$ Estimates from Gildemacher et al. (2009) have been averaged across districts and summarized to include 'seed grower' under the formal seed system and 'own field', 'neighbour' and 'rural markets' categories under the informal seed systems.

emphasized resistant varieties (Orton, 1914) as well as a number of on-farm management techniques to maintain or improve seed health, such as establishing seed plots, tuber-uniting, roguing and plant selection (see Table 2 for definitions) (Whipple, 1919). Such techniques continue to be routinely used by seed producers in certified seed production systems (Frost et al., 2013). In the Andes, farmers have traditionally sought seed from higher altitudes knowing it was of higher quality (Thiele, 1999). Furthermore, there is reason to believe that many of the native potato varieties have resistance and/or tolerance to the major yield-reducing viruses indeed, major resistance genes against PVY, PVX and PLRV have been found in cultivated and wild potato species from the Andes such as Solanum andigena and Solanum chacoense (Solomon-Blackburn \& Barker, 2001; Velásquez et al., 2007). DiFonzo et al. (1995) determined that the critical threshold for management of green peach aphid could be relaxed depending on the level of PLRV-resistance in potato varieties.
In the case of bacterial wilt management, the combined use of partially resistant varieties, healthy seed, and improved cultural practices resulted in greater reduction in wilt incidence and increased tuber yield compared with applying the components individually (Lemaga et al., 2005). For soilborne diseases that are indigenous to a region, planning management at a community level may also be critical. Although the incidence of bacterial wilt can be alarmingly high in many potato growing areas, pathogen prevalence is highly variable (Hayward, 1991). A better understanding of the interaction between environmental factors and management practices at higher levels of geographical aggregation (rather than only in individual fields or farms) is necessary to use this variability to the producers' advantage. Under such circumstances, community-based farmer capacity building programmes for on-farm seed management are likely to create costefficient solutions.

These examples represent two major areas of intervention that can be used to manage seed health: host plant resistance and on-farm management practices. Strategic use of these two approaches, together with purchase of certified (or other types of high quality) seed when economically viable, leads to an integrated strategy for managing seed health (Fig. 3). Integration can provide synergies among the three types of intervention. For example, periodic introduction of certified seed into a system may be much more effective if the variety involved has resistance to one or more degeneration pathogens. On-farm practices such as plant selection and vector management would also decrease degeneration in certified tuber stocks, maintaining the value of high quality seed and making the option to buy certified seed every few years more attractive.

Evidence of usefulness of host resistance and on-farm management

Several seed degeneration studies have compared two or more varieties, sometimes with known levels of resistance, and indicated differences in yield loss. Studies in two locations in India indicated that after four seasons of field cultivation the local variety Kufri Jyoti had lower yield reduction due to viral degeneration than did Kufri Giriraj (Ali et al., 2013). In Kenya, after four seasons, the overall yield reduction in genotypes resistant to multiple viruses ranged from 5 to $33 \%$ while the yield reduction in the local Ugandan and Kenyan varieties ranged from 56 to 58\% (John et al., 2013). In Uganda and Kenya, where bacterial wilt is endemic but chemical and cultural control is minimal, resistance to bacterial wilt is considered an important attribute of improved varieties. For example, although the variety Rutuku is high yielding with locally preferred red skin 
and moderate resistance to late blight, it has been abandoned by Ugandan farmers due to its high susceptibility to bacterial wilt (Kaguongo et al., 2008). These studies indicate that host plant resistance has potential to reduce the rate of degeneration.

Plant selection involves the use of symptomless plants, identified by visual inspection before senescence, as the seed source for the next season (Bryan, 1983; Gildemacher et al., 2011). In field studies with viral diseases, after one cycle of plant selection, this method led to a yield increase of 23-35\% (SchulteGeldermann et al., 2012), 28-53\% (Gildemacher et al., 2011), 39\% (Alvarez, 1988) and 7-44\% (J. L. AndradePiedra, unpublished results), while simultaneously lowering virus incidence. Epidemiologically, plant selection is similar to using certified seed in that it reduces the level of primary inoculum in the field. However, because the method relies on symptom recognition, effective farmer training is critical for the success of this strategy.

Roguing reduces inoculum sources in the field, reducing pathogen spread. This method also relies on farmer training in symptom recognition and works best when growers synchronize roguing over large areas (Sisterson \& Stenger, 2013). In potato, studies on the usefulness of roguing against viral diseases indicate variable success. In one study the method reduced tuber infection by PLRV by about $30-45 \%$, but this depended on the level of vector infestation in the field (Ioannou, 1989). Another study indicated that roguing was more effective against PVY than against PLRV and that early roguing was more effective than late roguing (Broadbent et al., 1950). Because aphid alighting can be affected by gaps in the crop canopy, roguing giving rise to gaps $\geq 0.6$ $\mathrm{m}^{2}$ can result in greater incidence of PVY (Davis et al., 2009). If infected plants produce useable yield, roguing can reduce overall crop yield (Sisterson \& Stenger, 2013). Adjacent healthy plants may compensate for yield loss if diseased plants are removed (Salazar, 1996), but in practice workers in many developing countries have noted that farmers rarely remove plants that may serve as a source of food (G. A. Forbes, personal observation). Although roguing may reduce yield within one season, roguing used over successive cycles of propagation would reduce seed degeneration and thereby increase yield, especially in the absence of other degeneration management strategies. This is assuming that care is taken to move diseased plants (and tubers, if late roguing is practised) away from the yield and destroy them, preventing spread of disease during their removal. Scientific demonstration of the costs and benefits of roguing is needed to clarify its field usefulness.

Early-season crop hygiene, the practice of removing alternate weed hosts and volunteer plants, can delay the onset of disease. Volunteer potato plants (also called groundkeepers), are potato plants growing from TPS or potatoes left behind after harvest and can serve as sources of primary inoculum (Askew \& Struik, 2007). Volunteer plants are of particular concern in cool temperature regions where most solanaceous plants die in the winter months and vectors normally overwinter on hosts that do not harbour virus populations (Robert et al., 2000). In warmer climates, removal of both alternate hosts and volunteer plants should also be important in reducing initial inoculum, although the authors are not aware of studies that demonstrate this.

Vectors play the most important role in the secondary spread of viruses within a field and, although vector management is an integral part of producing certified seed, it can be expensive and often beyond the reach of small-scale potato farmers. In addition, routine, indiscriminate use of pesticides has resulted in the emergence of resistant populations of aphids (van Toor et al., 2009). Alternatively, growing border crops such as soybean, wheat or resistant potato varieties around the edge of a potato field can limit nonpersistently transmitted viruses that are attracted to the colour contrast (brown soil versus green crop) at the edges (Radcliffe \& Ragsdale, 2002; Boiteau et al., 2009). Other management strategies, such as straw mulching to affect aphid flight activity (Saucke \& Döring, 2004), polymer webs used as protective plant cover (Harrewijn et al., 1991), pheromone traps, and insecticidal soap to alter aphid feeding, can also be used and may hold greater promise for resource-poor farmers.

The choice of field sites and selection of planting date can also maintain low disease incidence in seed by disease avoidance. Aphid monitoring studies have revealed that vector incidence and resulting virus pressure are much lower at higher elevations (Vucetic et al., 2013; Ali et al., 2015) and that there are temporal peaks of vector abundance in the field (Carli \& Baltaev, 2008). Pre-sprouting tubers prior to planting can result in earlier emergence and escape from pathogens or vectors that are more abundant later in the growing season (Hospers- Brands et al., 2008). Ensuring that seed potato plots are harvested before harvest of adjacent fields, thereby avoiding heavy vector flights from adjacent crops, can also reduce spread of disease. Large-scale vector incidence monitoring studies can provide an objective basis for identifying sites and cultivars (early- versus late-maturing) better suited for seed multiplication in a region.

Other management practices such as tuberuniting, varietal mixtures and crop rotations can also be useful against degeneration. Tuber-uniting is the practice of dividing seed tubers into four pieces and planting them consecutively. The practice increases the efficacy of roguing because groups of infected plants are more easily identified than individual plants and allows the removal of all of the seed pieces that originated from 
an infected tuber. Tuber-uniting is useful for farmers who plant cut-seed and practice roguing, although sterilization of cutting knives is critical to prevent the spread of bacterial or viral pathogens in a seed lot. The use of varietal mixtures to control Phytophthora infestans can reduce disease incidence, especially when highly resistant varieties are included with susceptible varieties (Phillips et al., 2005; Garrett et al., 2009). For soilborne degenerative diseases, crop rotation plays a major role in lowering field inoculum pressure. Rapeseed used as green manure, compared with rotation with oats, led to a 70-80\% reduction in the incidence of $R$. solani in the following season (Larkin \& Griffin, 2007), and disease suppression has also been observed against bacterial wilt ( $R$. solanacearum) when the legume Crotalaria falcate was used in crop rotations (Kakuhenzire et al., 2013). In addition to known biofumigant properties of some green manure crops (e.g. Brassica spp.), increasing organic matter in the soil encourages the growth of mycophagous soil mesofauna that aid in disease suppression (Scholte \& Lootsma, 1998).

Opportunity costs of the certified seed replacement paradigm

Many reasons have been given for the failure of certified seed replacement systems in developing countries (Thiele, 1999). The authors propose that the research and development initiatives that have driven potato seed interventions in developing countries for the last five decades or more (Crissman, 1989; Crissman et al., 1993; Kadian et al., 2007; Hidalgo et al., 2009; Gildemacher et al., 2012) need to be critically scrutinized. The nearexclusive emphasis on certified seed replacement systems (Fig. 3) has adversely affected international, national and regional research agendas. Current efforts to deal with the problem of low quality seed potato in developing countries focus on either improving existing formal systems or establishing new ones. Few resources are available to improve host plant resistance levels, refine and implement plant selection at the field level, and promote pest and disease avoidance, all of which may have immediate impact by improving the quality of on-farm seed.

Adding to these challenges are draconian seed laws enforced in some countries. In Kenya, for example, the tolerance for certain diseases such as bacterial wilt is nil for any grade of seed tubers from basic seed (progeny of certified breeder's seed or certified pre-basic seed) to third generation certified seed (progeny of first or second generation certified seed) (Sikinyi, 2000). Similarly, in Uganda, bacterial wilt incidence is required to be nil during any field inspection (Ssebuliba, 2010). Given that bacterial wilt is endemic in many seed production areas, and that there is a lack of resistant varieties, the feasibility of achieving such thresholds is questionable, not to mention the enormous costs and consequently high price of seed tubers necessary to make the operation profitable. In mature systems such as the Wisconsin seed potato certification programme, thresholds were developed based on what works for farmers in an area rather than 'transplanting' thresholds established elsewhere (A. O. Charkowski, personal observation). Similarly, quality-declared seed, where some flexibility is allowed in implementing quality standards, would serve as a good alternative in regions where activities to maintain high standards are difficult (FAO, 2006). Thus, an approach where 'the perfect is the enemy of the good', where establishment of perfect thresholds for disease is given higher priority than using realistic but 'good' thresholds, can slow or derail even the smallest penetration of certified seed into informal seed systems of developing countries.

\section{Conclusions and considerations}

The certified seed replacement paradigm, successfully established in developed countries, has had limited impact in improving the health of on-farm seed in developing countries. Because most small-scale farmers get seed material as a by-product of their own ware potato crops or from local informal sources, a degeneration management strategy should include improvement of the health status of seed from these sources. To facilitate integrated and interdisciplinary approaches, the authors consider all seed health problems that may accumulate in tubers over successive cycles of vegetative propagation as causes of degeneration, including some insect pests and nematodes. The integrated seed health strategy, which in addition to strategic use of certified seed encourages the use of host resistance and on-farm management tools, is intended to offer a realistic solution to managing degeneration in informal seed production systems. Some critical research areas that would aid in the implementation of an integrated approach are elaborated below.

Improved estimation of on-farm yield reduction due to seed degeneration

Estimating the impact of agricultural pests on yield is a critical element for prioritizing research agendas and establishing economic thresholds for use of management components. Although yield reduction due to individual pathosystems has been studied, overall reduction due to seed degeneration in the field is rarely the sum of their parts. Synergistic and antagonistic interactions between pathogens can increase or reduce the severity of seed degeneration. Further, as seed degeneration is due to accumulation of pathogens and/or 
pests over multiple generations, long-term studies of yield reduction are critical for impact assessment. One such globally collaborative study is currently underway as a part of the CGIAR Research Program on Roots, Tubers and Bananas (RTB). Potato seed degeneration trials, aimed at understanding the efficacy of resistance and management practices on seed degeneration, have been established in diverse agroclimatic regions of Ecuador, China, Kenya and Ethiopia.

Better understanding of cultivar resistance to degenerative diseases

Given the near-absence of certified seed replacement in developing countries, it is assumed that host genotype already plays a major role in the level of degeneration currently experienced in those parts of the world. High levels of resistance in individual plants and a mosaic of such hosts in a region can, in theory, reduce disease spread. However, despite the apparent availability of many such cultivars, their acceptance and deployment in a region can be affected by many factors including farmer and end-user preferences, environmental stability of resistance and the incidence of pathogens causing seed degeneration. A deeper appreciation of these factors is important for integrating host resistance into seed degeneration management. Given the multipathogen nature of degeneration in many cases, it is also important to understand the overall epidemiological effect of high levels of resistance to one pathogen versus moderate levels of resistance to multiple pathogens. In addition, phenomena such as autoinfection and mature plant resistance vary with elevation, pathogen type and cultivars (Bertschinger, 1992; Radcliffe \& Ragsdale, 2002). Studies to clarify whether these phenomena have a heritable genetic basis would greatly aid the development of resistant varieties. Finally, a major impediment to greater use of host plant resistance is the absence of a common, quantitative system for assessing resistance phenotypes.

Interdisciplinary research evaluating the efficiency and adoption of on-farm integrated seed health strategy

Management practices proven to have epidemiological utility should have high efficacy across agroecological zones. Additionally, assessing the cost-benefit ratios of management components (applied for one year and multiple years) would be crucial to develop reliable recommendations for resource-poor farmers. In developing countries, the need for collective action in the farming community was identified as a key obstacle to improve the adoption rates of integrated pest management practices (Parsa et al., 2014). Studies on information diffusion and adoption of agricultural innovations have indicated the critical and interdependent roles played by extension services and farmer social networks for establishing effective communication channels (Garrett, 2012; Genius et al., 2014). Research on social modelling and the psychology of decision making, integrated with research on biotic, economic and environmental traits affecting seed degeneration, is thus much needed. Studies employing interdisciplinary diagnostic methods such as technography (see Table 2 for definition) to understand the contexts that determine the performance of a technology (Jansen \& Vellema, 2011) are particularly relevant for degeneration management.

Improved insights into epidemiology of degeneration and interrelationships between risk factors

Understanding the epidemiology of year-round disease maintenance in seed is useful for better management of seed degeneration. Mixed infections of viruses are commonly observed in potato seed obtained via the informal seed system (Gildemacher et al., 2009). Understanding species- and strain-specific factors, especially in relation to host resistance and environmental cues, is important to tailor a subset of highly effective management practices for the predominant causes of seed degeneration in a region. The RTB project on degeneration mentioned above has, as one of its objectives, the development of models to predict degeneration that include the effects of host resistance and environmental factors. Such models would aid understanding of the interrelated risk factors of seed health and the development of agricultural interventions and decision support tools at the scale of individual farmers or communities. Using such decision support systems, local governmental and nongovernmental extension agencies would be able to provide practical recommendations to growers to implement the integrated seed health strategy.

Understanding the impact of climate change on potato seed degeneration

In a recent study by van der Waals et al. (2013), the aphid population in specific agroecosystems in South Africa was predicted to increase by 2050. This in turn could increase outbreaks of PVY and PLRV epidemics. Virus replication and movement rates can be affected by climate change (Canto et al., 2009), and potato tuber infection is temperature sensitive, with increased susceptibility in warmer temperatures (Bertschinger et al., 1995b). Together with new and emerging tuberborne infections, these studies suggest that degeneration of potato is likely to become a greater challenge in the coming decades, with predicted increasing temperatures. 
Using positive deviance to improve management of potato seed production

In communities of people struggling with a common health or food production problem, there are sometimes people who succeed, even though they do not have obvious access to additional resources outside those available to everyone in the community (Marsh et al., 2004). These creative individuals hold the solution to using locally available resources to manage a complex problem and should be sought out by those hoping to understand how to better address the challenge. This approach, known as 'positive deviance', has been used to improve health, nutrition and education in multiple communities (Marsh et al., 2004). It has rarely been used to deliberately address agricultural challenges (Oyarzun et al., 2013), even though extension workers often identify successful farms. The integrated seed health strategy is essentially a public health approach to potato production, encouraging farmers to use multiple approaches to address a complex problem. Educational tools (that use the same vocabulary, metaphors and concepts) used for animal and human health may be employed to address multiple types of health problems, including potato seed health.

Understanding how the combination of 'business ecosystem' and agroecosystem influences the success of seed degeneration management

A 'business ecosystem' includes a set of businesses and their interactions necessary for any given business to be successful (Iansiti \& Levien, 2004). Many applications of the concept can be found in the IT industry, where compatibilities and synergies among products are needed for businesses to succeed. The set of businesses and stakeholders in seed systems can be thought of as a business ecosystem, where there is a need for greater understanding of the environmental and socioeconomic conditions necessary for successful implementation of the integrated seed health strategy. Research should address how to identify and support the conditions that make management components viable. Certified seed plantings are vulnerable to rapid infection from other sources, so management choices of neighbouring farmers and their seed suppliers will influence the success of any given farmer. Agroecological conditions in tropical countries may also be more favourable to inoculum build-up. Given this, what local pathogen population threshold would make certified seed systems viable, and what system components are necessary to keep populations below the threshold? Similarly, implementation of techniques such as plant selection requires that farmers be familiar with disease symptoms and have labour available. What system components are necessary to make such on-farm management successful? Ultimately it will also be important to understand how different seed systems are more or less resilient to different shocks, such as the introduction of new pathogens or unusually disease/pest-conducive weather conditions (Folke, 2006).

Many interrelated factors in the biology, socioeconomics, and policy of potato seed play crucial roles in the effective management of seed degeneration in potato. Some challenges such as the unpredictability of seed degeneration in on-farm seed material, unavailability of resistant varieties, and lack of approaches to objectively integrate management strategies across agroecological zones, emphasize the need for more research initiatives. Other challenges, such as the uptake of seed regeneration methods (e.g. plant selection), deployment of resistant varieties, and establishment of profitable seed production systems, require translational research, improved farmer education and research into the socioeconomics and behavioural economics of using certified seed. Yet other challenges, such as developing realistic tolerance thresholds in certified seed systems, and establishing a research and development agenda that focuses on the integrated seed health strategy, require improved policy and regulations for seed degeneration management. Such a multipronged approach is likely to be successful in managing this devastating problem for potato producers in many developing countries.

\section{Acknowledgements}

This study was funded by the CGIAR Research Program for Roots, Tubers and Bananas, the CGIAR Research Program on Climate Change, Agriculture and Food Security (CCAFS), the Kansas Agricultural Experiment Station (contribution no. 15-333-J), the Scottish Government's RESAS division, McKnight Foundation for the projects 'Strengthening systems for native seed potato in Bolivia, Ecuador, and Peru' and 'Understanding potato seed degeneration in Ecuador', Indian Council of Agricultural Research, and USDA Specialty Crop Research Initiative Grant (project no. 2009-02768). The authors appreciate comments from $\mathrm{G}$. Thiele and J. F. Kreuze, and the helpful review from Plant Pathology. The authors confirm that they have no conflicts of interest.

\section{References}

Ali S, Kadian MS, Ortiz O, Singh BP, Chandla VK, Akhtar M, 2013. Degeneration of potato seed in Meghalaya and Nagaland states in north-eastern hills of India. Potato Journal 40, 122-7. 
Ali S, Kadian MS, Akhtar M et al., 2015. Potato virus-vector aphid epidemiology in North Eastern hills of India. National Academy of Science Letters 38, 139-42.

Almekinders C, 2000. The importance of informal seed sector and its relation with the legislative framework. Paper presented at GTZEschborn. [http://citeseerx.ist.psu.edu/viewdoc/download?doi=10_1 _1_195_468\&rep=rep1\&type=pdf]. Accessed 22 July 2015.

Alvarez EV, 1988. Método simple de selección para la producción desemilla de papa. Revista Latinoamericana de la Papa 1, 18-24.

Askew MF, Struik PC, 2007. The canon of potato science: 20 Volunteer potatoes. Potato Research 50, 283-7.

Bertschinger L, 1992. Modelling of Potato Virus Pathosystems by Means of Quantitative Epidemiology: An Exemplary Case Based on Virus Degeneration Studies in Peru. Zurich, Switzerland: Swiss Federal Institute of Technology, $\mathrm{PhD}$ thesis.

Bertschinger L, Scheidegger UC, Luther K, Pinillos O, Hidalgo A, 1990. La incidencia de virus de papa en cultivares nativos y mejorados en la sierra peruana. Revista Latinoamericana de la Papa 3, 62-79.

Bertschinger L, Keller ER, Gessler C, 1995a. Development of EPIVIT, a simulation model for contact- and aphidtransmitted potato viruses. Phytopathology 85, 801-14.

Bertschinger L, Keller ER, Gessler C, 1995b. Characterization of the virus $\mathrm{x}$ temperature interaction in secondarily infected potato plants using EPIVIT. Phytopathology 85, 815-9.

Boiteau G, Singh M, Lavoie J, 2009. Crop border and mineral oil sprays used in combination as physical control methods of the aphid transmitted potato virus $\mathrm{Y}$ in potato. Pest Management Science 65, 255-9.

van den Bosch F, Jeger MJ, Gilligan CA, 2007. Disease control and its selection for damaging plant virus strains in vegetatively propagated staple food crops; a theoretical assessment. Proceedings of the Royal Society B: Biological Sciences 274, 11-8.

Broadbent L, Gregory PH, Tinsley TW, 1950. Roguing potato crops for virus diseases. Annals of Applied Biology 37, 640-50.

Brown BA, 1929. The Causes of Degeneration of Irish Potatoes in Connecticut. Storrs, CT, USA: University of Connecticut Agricultural Experiment Station Bulletin 160.

Bryan JE, 1983. On-farm Seed Improvement by the Potato Seed Plot Technique. Lima, Peru: International Potato Center, Technical Information Bulletin 7.

Canto T, Aranda MA, Fereres A, 2009. Climate change effects on physiology and population processes of hosts and vectors that influence the spread of hemipteran-borne plant viruses. Global Change Biology 15, 1884-94.

Carli C, Baltaev B, 2008. Aphids infesting potato crop in the highlands of Uzbekistan. Potato Journal 35, 134-40.

Crissman CC, 1989. Seed Potato Systems in the Philippines: A Case Study. Lima, Peru: International Potato Center.

Crissman CC, McArthur Crissman L, Carli C, 1993. Seed Potato Systems in Kenya: A Case Study. Lima, Peru: International Potato Center.

Cromme N, Prakash AB, Lutaladio N, Ezeta F, 2010. Strengthening Potato Value Chains. Technical and Policy
Options for Developing Countries. Rome, Italy: Food and Agriculture Organization of the United Nations and the Common Fund for Commodities.

Crosslin JM, Hamlin LL, Buchman JL, Munyaneza JE, 2011. Transmission of potato purple top phytoplasma to potato tubers and daughter plants. American Journal of Potato Research 88, 339-45.

Davis JA, Radcliffe EB, Ragsdale DW, 2009. Planter skips and impaired stand favors Potato virus $Y$ spread in potato. American Journal of Potato Research 86, 203-8.

Devaux A, Kromann P, Ortiz O, 2014. Potatoes for sustainable global food security. Potato Research 57, 185-99.

DiFonzo CD, Ragsdale DW, Radcliffe EB, 1995. Potato leafroll virus spread in differentially resistant potato cultivars under varying aphid densities. American Potato Journal 72, 119-32.

Döring TF, 2011. Potential and limitations of plant virus epidemiology: lessons from the Potato virus $Y$ pathosystem. Potato Research 54, 341-54.

Draper MD, Pasche JS, Gudmestad NC, 2002. Factors influencing PVY development and disease expression in three potato cultivars. American Journal of Potato Research 79, 155-65.

Dung JKS, Ingram JT, Cummings TF, Johnson DA, 2012. Impact of seed lot infection on the development of black dot and Verticillium wilt of potato in Washington. Plant Disease 96, 1179-84.

Elphinstone JG, 2005. The current bacterial wilt situation: a global overview. In: Allen C, Prior P, Hayward AC, eds. Bacterial Wilt Disease and the Ralstonia solanacearum Species Complex. St Paul, MN, USA: American Phytopathological Society, 9-28.

ESPAC, 2012. Encuesta de superficie y producción agropecuaria continua. [www.ecuadorencifras.gob.ec/wpcontent/descargas/ Presentaciones/PRESENTACIONEspac.pdf]. Accessed 13 October 2014.

Fankhauser C, 2000. Seed-Transmitted Diseases as Constraints for Potato Production in the Tropical Highlands of Ecuador. Zurich, Switzerland: Swiss Federal Institute of Technology, PhD thesis.

FAO, 2006. Quality Declared Seed System. Rome, Italy: Food and Agriculture Organization of the United Nations Plant Production and Protection Paper 185.

FAO, 2011. Food and Agriculture Organization of the United Nations, FAOSTAT database.

[http://faostat.fao.org/site/368/default.aspx\#ancor]. Accessed 6 June 2015.

FAO, 2013. Food and Agriculture Organization of the United Nations, FAOSTAT database. [http://faostat.fao.org/site/567/default.aspx\#ancor]. Accessed 6 June 2015.

FEDEPAPA, 2010. Acuerdo de competitividad de la cadena agroalimentaria de la papa. [www.fedepapa.com/wpcontent/uploads/pdf/ACUERDO-COMPETITIVIDADCADENAAGROALIMENTARIA-PAPA.pdf]. Accessed 13 October 2014.

Fiers M, Edel-Hermann V, Chatot C, Hingrat YL, Alabouvette C, Steinberg C, 2012. Potato soil-borne diseases. A review. Agronomy for Sustainable Development 32, 93-132. 
Folke C, 2006. Resilience: the emergence of a perspective for social-ecological systems analyses. Global Environmental Change 16, 253-67.

Folsom D, Schultz ES, Bonde R, 1926. Potato Degeneration Diseases: Natural Spread and Effect upon Yield. Orono, ME, USA: Maine Agricultural Experiment Station, Bulletin 331.

Frost KE, Groves RL, Charkowski AO, 2013. Integrated control of potato pathogens through seed potato certification and provision of clean seed potatoes. Plant Disease 97, 1268-80.

Fuglie KO, 2007. Priorities for potato research in developing countries: results of a survey. American Journal of Potato Research 84, 353-65.

Garrett KA, 2012. Information networks for plant disease: commonalities in human management networks and within-plant signaling networks. European Journal of Plant Pathology 133, 75-88.

Garrett KA, Zúñiga LN, Roncal E et al., 2009. Intraspecific functional diversity in hosts and its effect on disease risk across a climatic gradient. Ecological Applications 19, 1868-83.

Genius M, Koundouri P, Nauges C, Tzouvelekas V, 2014. Information transmission in irrigation technology adoption and diffusion: social learning, extension services, and spatial effects. American Journal of Agricultural Economics 96, 328-44.

Gildemacher PR, Demo P, Barker I et al., 2009. A description of seed potato systems in Kenya, Uganda and Ethiopia. American Journal of Potato Research 86, 373-82.

Gildemacher PR, Schulte-Geldermann E, Borus D et al., 2011. Seed potato quality improvement through positive selection by smallholder farmers in Kenya. Potato Research 54, 253-66.

Gildemacher PR, Leeuwis C, Demo P et al., 2012. Positive selection in seed potato production in Kenya as a case of successful research-led innovation. International Journal of Technology Management \& Sustainable Development 11, 67-92.

Golizadeh A, Esmaeili N, Razmjou J, Rafiee-Dastjerdi H, 2014. Comparative life tables of the potato tuberworm, Phthorimaea operculella, on leaves and tubers of different potato cultivars. Journal of Insect Science 14, $1-11$.

Govinden N, 1990. Intercropping of sugar-cane with potato in Mauritius: a successful cropping system. Field Crops Research 25, 99-110.

de Graaf J, 1994. Plant health and international trade in seed potatoes. Canadian Journal of Plant Pathology 16, 1469.

Guzmán-Barney M, Franco-Lara L, Rodr_1guez D, Vargas L, Fierro JE, 2012. Yield losses in Solanum tuberosum group phureja cultivar Criolla Colombia in plants with symptoms of PYVV in field trials. American Journal of Potato Research 89, 438-47.

Harrewijn P, den Ouden H, Piron PGM, 1991. Polymer webs to prevent virus transmission by aphids in seed potatoes. Entomologia Experimentalis et Applicata 58, 101-7.

Hayward AC, 1991. Biology and epidemiology of bacterial wilt caused by Pseudomonas solanacearum. Annual Review of Phytopathology 29, 65-87.
Henne DC, Workneh F, Wen A et al., 2010. Characterization and epidemiological significance of potato plants grown from seed tubers affected by zebra chip disease. Plant Disease 94, 659-65.

Hidalgo OA, Manrique K, Velasco C, Devaux A, Andrade Piedra JL, 2009. Diagnostic of seed potato systems in Bolivia, Ecuador and Peru focusing on native varieties. In: 15th International Society for Tropical Root Crops. Tropical Roots and Tubers in a Changing Climate: A Critical Opportunity for the World. Lima, Peru: International Potato Center, Universidad Nacional Agraria La Molina, 41-6.

Hospers-Brands AJTM, Ghorbani R, Bremer E et al., 2008. Effects of presprouting, planting date, plant population and configuration on late blight and yield of organic potato crops grown with different cultivars. Potato Research 51, 131-50.

Hossain M, Ali MS, Rashid MM, 1994. Effect of inoculum levels of potato virus Y (PVY) on yield and subsequent spread of the disease under insecticide spray and unsprayed condition. Bangladesh Journal of Botany 23, 87-91.

Iansiti M, Levien R, 2004. Strategy as ecology. Harvard Business Review 82, 1-11.

Ilangantileke SG, Kadian MS, Hossain M, Hossain AE, Jayasinghe U, Mahmood AA, 2001. Toward alleviating poverty of rural potato farmers by strengthening the potato seed system in Bangladesh: a rapid rural appraisal. In: Scientist and Farmer: Partners in Research for the 21 st Century. Program Report 1999-2000. Lima, Peru: International Potato Center, 259-64.

Ioannou N, 1989. Production of seed potatoes in Cyprus: the effects of roguing and planting date on the spread of potato leaf roll virus, tuber yield, and infestation by potato tuber moth. Potato Research 32, 331-9.

Iritani WM, 1968. Factors affecting physiological aging (degeneration) of potato tubers used as seed. American Journal of Potato Research 45, 111-6.

ISTA, 2014. International rules for seed testing: rules 2014. [www.seedtest.org/rules]. Accessed 19 August 2014.

Jansen K, Vellema S, 2011. What is technography? NJAS Wageningen Journal of Life Sciences 57, 169-77.

John O, Kiarie N, Solomon S, 2013. Improving potato tuber yields using genotypes with multiple virus resistance in Kenya. Agriculture and Biology Journal of North America 4, 406-12.

Kadian MS, Ilangantileke S, Arif M et al., 2007. Status of potato seed systems in South West Asia (SWA). Potato Journal 34, 25-30.

Kadian MS, Arif M, Ilangantileke S, 2009. Improving livelihood of potato farmers in Afghanistan. In: Yadav JSP, Singh RK, Gupta VP, eds. Converting Deserts into Oasis. New Delhi, India: Star Books Distributors, 20916.

Kaguongo W, Gildemacher P, Demo P et al., 2008. Farmer Practices and Adoption of Improved Potato Varieties in Kenya and Uganda. Lima, Peru: International Potato Center.

Kaguongo W, Maingi G, Barker I, Nganga N, Guenthner J, 2014. The value of seed potatoes from four systems in Kenya. American Journal of Potato Research 91, 10918. 
Kakuhenzire R, Lemaga B, Kashaija I, Ortiz O, Mateeka B, 2013. Effect of Crotalaria falcata in crop rotation and fallowing on potato bacterial wilt incidence, disease severity and latent infections in tubers and field soil. Biopesticides International 9, 182-94.

Kawakami K, 1962. The physiological degeneration of potato seed tubers and its control. Potato Research 5, 40-9.

Labarta RA, 2013. Possibilities and opportunities for enhancing availability of high quality seed potato in Ethiopia: lessons from the successful $3 \mathrm{G}$ project in Kenya. In: Woldegiorgis G, Schulz S, Berihun B, eds. Seed Potato Tuber Production and Dissemination. Experiences, Challenges and Prospects. Proceedings of the National Workshop on Seed Potato Tuber Production and Dissemination, 2012. Bahir Dar, Ethiopia: Ethiopian Institute of Agricultural Research and Amhara Regional Agricultural Research Institute, 21-34.

Larkin RP, Griffin TS, 2007. Control of soilborne potato diseases using Brassica green manures. Crop Protection 26, 1067-77.

Lemaga B, Kakuhenzire R, Kassa B, Ewell PT, Priou S, 2005. Integrated control of potato bacterial wilt in Eastern Africa: the experience of African highlands initiative. In: Allen C, Prior P, Hayward AC, eds. Bacterial Wilt Disease and the Ralstonia solanacearum Species Complex. St Paul, MN, USA: American Phytopathological Society, 145-57.

Li Y-Y, Zhang R-N, Xiang H-Y et al., 2013. Discovery and characterization of a novel carlavirus infecting potatoes in China. PLoS ONE 8, e69255.

Lutaladio N, Castaldi L, 2009. Potato: the hidden treasure. Journal of Food Composition and Analysis 22, 491-3.

Mannan AKMSB, Akanda AM, Bhuiyan MKA, Islam AKMS, 2008. Performance of six different potato varieties grown from seventh generation seed potato against PVY. Journal of Soil and Nature 2, 68-75.

Marsh DR, Schroeder DG, Dearden KA, Sternin J, Sternin M, 2004. The power of positive deviance. British Medical Journal 329, 1177-9.

Massee G, 1907. Plant diseases: VIII: degeneration in potatoes. Bulletin of Miscellaneous Information (Royal Gardens, Kew) 8, 307-11.

Mateus-Rodriguez JR, de Haan S, Andrade-Piedra JL et al., 2013. Technical and economic analysis of aeroponics and other systems for potato mini-tuber production in Latin America. American Journal of Potato Research 90, 35768.

Monares A, 1988. Analytical framework for design and assessment of potato seed programs in developing countries. In: Proceedings of the 3rd Planning Conference on the Social Sciences at CIP. Lima, Peru: International Potato Center, 247-61.

Muthoni J, Shimelis H, Melis R, 2013. Alleviating potato seed tuber shortage in developing countries: potential of true potato seeds. Australian Journal of Crop Science 7, $1946-54$

Mwangi JK, Nyende AB, Demo P, Matiru VN, 2008. Detection of latent infection by Ralstonia solanacearum in potato (Solanum tuberosum) using stems instead of tubers. African Journal of Biotechnology 7, 1644-9.

Nolte P, Whitworth JL, Thornton MK, McIntosh CS, 2004. Effect of seedborne Potato virus $\mathrm{Y}$ on performance of
Russet Burbank, Russet Norkotah, and Shepody potato. Plant Disease 88, 248-52.

Orton WA, 1914. Potato Wilt, Leaf-Roll, and Related Diseases. Washington, DC, USA: US Department of Agriculture.

Oyarzun PJ, Mary Borja R, Sherwood S, Parra V, 2013. Making sense of agrobiodiversity, diet, and intensification of smallholder family farming in the highland Andes of Ecuador. Ecology of Food and Nutrition 52, 515-41.

Palukaitis P, Carr JP, 2008. Plant resistance responses to viruses. Journal of Plant Pathology 90, 153-71.

Panchi N, Navarrete I, Taipe A et al., 2012. Incidencia, severidad y pérdidas causadas por plagas de la semilla de papa en Ecuador. In: Memorias del XXV Congreso de la Asociación Latinoamericana de la Papa (ALAP), 17-20 September 2012. Uberlandia, Brazil: ALAP, [http://www.abbabatatabrasileira.com.br/images/eventos/ arquivos/ ALAP2012-0081.PDF]. Accessed 22 July 2015.

Parsa S, Morse S, Bonifacio A et al., 2014. Obstacles to integrated pest management adoption in developing countries. Proceedings of the National Academy of Sciences, USA 111, 3889-94.

Pathania N, Trevorrow P, Hughes M, Marton T, Justo V, Salvani J 2013. Preliminary research to develop a lowtechnology aeroponic system for producing clean seed potato in the Philippines. In: Oakeshott J, Hall D, eds. Smallholder HOPES - Horticulture, People and Soil. Proceedings of the ACIAR-PCAARRD Southern Philippines Fruits and Vegetables Program Meeting, 3 July 2012, Cebu, Philippines. Canberra, Australia: Australian Centre for International Agricultural Research Proceedings 139, 138-47.

Phillips SL, Shaw MW, Wolfe MS, 2005. The effect of potato variety mixtures on epidemics of late blight in relation to plot size and level of resistance. Annals of Applied Biology 147, 245-52.

Potato Certification Service, 2015. Potato Certification Service. [www.potatocertification.co.za]. Accessed 30 March 2015.

Radcliffe EB, Ragsdale DW, 2002. Aphid-transmitted potato viruses: the importance of understanding vector biology. American Journal of Potato Research 79, 353-86.

Rahman MS, Akanda AM, 2010. Effect of PLRV infected seed tuber on disease incidence, plant growth and yield parameters of potato. Bangladesh Journal of Agricultural Research 35, 359-66.

Rahman MS, Akanda AM, Mian IH, Bhuian MKA, Karim MR, 2010. Growth and yield performance of different generations of seed potato as affected by PVY and PLRV. Bangladesh Journal of Agricultural Research 35, 37-50.

Robert Y, Woodford JA, Ducray-Bourdin DG, 2000. Some epidemiological approaches to the control of aphid-borne virus diseases in seed potato crops in northern Europe. Virus Research 71, 33-47.

Salazar LF, 1996. Potato Viruses and their Control. Lima, Peru: International Potato Center.

Salazar LF, M€uller G, Querci M, Zapata JL, Owens RA, 2000. Potato yellow vein virus: its host range, distribution in South America and identification as a 
crinivirus transmitted by Trialeurodes vaporariorum. Annals of Applied Biology 137, 7-19.

Saucke H, Döring TF, 2004. Potato virus $Y$ reduction by straw mulch in organic potatoes. Annals of Applied Biology 144, 347-55.

Scholte K, Lootsma M, 1998. Effect of farmyard manure and green manure crops on populations of mycophagous soil fauna and Rhizoctonia stem canker of potato.

Pedobiologia 42, 223-31.

Scholthof K-BG, Adkins S, Czosnek H et al., 2011. Top 10 plant viruses in molecular plant pathology. Molecular Plant Pathology 12, 938-54.

Schulte-Geldermann E, Gildemacher PR, Struik PC, 2012. Improving seed health and seed performance by positive selection in three Kenyan potato varieties. American Journal of Potato Research 89, 429-37.

Shepard JF, Claftin LE, 1975. Critical analyses of the principles of seed potato certification. Annual Review of Phytopathology 13, 271-93.

Sikinyi EO, 2000. Baseline Study/Survey Report on the Seed Sector in Kenya. Nairobi, Kenya: Seed Trade Association of Kenya.

Sileshi G, Teriessa J, 2001. Tuber damage by potato tuber moth, Phthorimaea operculella Zeller (Lepidoptera: Gelechiidae), in the field in eastern Ethiopia. International Journal of Pest Management 47, 109-13.

Sisterson MS, Stenger DC, 2013. Roguing with replacement in perennial crops: conditions for successful disease management. Phytopathology 103, 117-28.

Solomon-Blackburn RN, Barker H, 2001. Breeding virus resistant potatoes (Solanum tuberosum): a review of traditional and molecular approaches. Heredity 86, $17-$ 35.

Ssebuliba RN, 2010. Baseline Survey of the Seed Sector in Uganda, in Relation to Regional Harmonization of Seed Legislation. Kampala, Uganda: Uganda Seed Trade Association.

Struik PC, Wiersema SG, 1999. Seed Potato Technology. Wageningen, Netherlands: Wageningen University Press.

Thiele G, 1999. Informal potato seed systems in the Andes: why are they important and what should we do with them? World Development 27, 83-99.

van Toor R, Malloch G, Fenton B, 2009. A concept for management of aphid virus-vectors and insecticide resistance in Myzus persicae on potatoes in Scotland. Redia XCII, 21, 9-21.

Toth IK, van der Wolf JM, Saddler G et al., 2011. Dickeya species: an emerging problem for potato production in Europe. Plant Pathology 60, 385-99.

Tripp R, 1997. The structure of national seed systems. In: Tripp R, ed. New Seed and Old Laws: Regulatory Reform and the Diversification of National Seed Systems. London, UK: Overseas Development Institute, 14-42.

Tufa AH, 2013. Economic and Agronomic Analysis of the Seed Potato Supply Chain in Ethiopia. Wageningen, Netherlands: Wageningen University, PhD Thesis.

Vanloqueren G, Baret PV, 2009. How agricultural research systems shape a technological regime that develops genetic engineering but locks out agroecological innovations. Research Policy 38, 971-83.

Velásquez AC, Mihovilovich E, Bonierbale M, 2007. Genetic characterization and mapping of major gene resistance to potato leafroll virus in Solanum tuberosum ssp. andigena. Theoretical and Applied Genetics 114, 1051-8.

Vucetic A, Jovicic I, Petrovic-Obradovic O, 2013. The pressure of aphids (Aphididae, Hemiptera), vectors of potato viruses. Archives of Biological Sciences 65, 65966.

van der Waals JE, Kr€uger K, Franke AC, Haverkort AJ, Steyn JM, 2013. Climate change and potato production in contrasting South African agro-ecosystems. 3: Effects on relative development rates of selected pathogens and pests. Potato Research 56, 67-84.

Were HK, Kabira JN, Kinyua ZM et al., 2013. Occurrence and distribution of potato pests and diseases in Kenya. Potato Research 56, 325-42.

Whipple OB, 1919. Degeneration in Potatoes. Montana, USA: University of Montana Agricultural Experiment Station: Montana Agricultural Experiment Station Bulletin no. 130.

Whitehead T, 1924. Potato leaf-roll and degeneration in yield. Annals of Applied Biology 11, 31-41.

Whitehead T, 1930. A study of the degeneration of certain potato stocks. Annals of Applied Biology 17, 452-86. 